\title{
Effects of Indigenous and Non-Indigenous Arbuscular Mycorrhizal Fungi on Growth and Plant Nutrient Uptake by Terung Asam (Solanum lasiocarpum Dunal)
}

\author{
MUHAMMAD AKMAL SHAHUDIN, JOHN KEEN CHUBO*, KIAN HUAT ONG \& \\ CARLINA FREDDIE SIMOL
}

\author{
Faculty of Agricultural Science and Forestry, Universiti Putra Malaysia Bintulu Sarawak Campus, 97008 \\ Bintulu, Sarawak \\ *Corresponding author: johnkeen@upm.edu.my \\ Received: 4 September $2021 \quad$ Accepted: 26 October $2021 \quad$ Published: 31 December 2021
}

\begin{abstract}
Terung asam (Solanum lasiocarpum Dunal) is a native fruit vegetable that is gaining interest as a commercial crop in Sarawak and Malaysia. Malaysia is covered by soils that are highly weathered, acidic, and low in fertility and depend on chemical fertilisers to promote good plant growth. Alternative means to reduce dependency on chemical fertiliser, for example arbuscular mycorrhiza fungi (AMF), must be sourced. Very few research on terung asam has been documented particularly on nutrients uptake. The objectives of this research were to investigate the effect of indigenous and non-indigenous AMF on nutrient uptake by terung asam. A greenhouse experiment was conducted consisting of three treatments namely control (T1), indigenous AMF (T2), non-indigenous AMF (T3). The treatments were arranged in a complete randomised design with four subsamples and four replicates. Thirty-day-old seedlings were transplanted and measured for their heights and stem diameters for 90 days. Fresh and dry shoot and root weights were taken during harvesting. Plant nutrient analyses were conducted using Kjeldahl method for total N, single ashing for P and single ashing and double acid for $\mathrm{K}, \mathrm{Ca}$ and $\mathrm{Mg}$. The results revealed the addition of AMF spores at 200 spores per pot, increased plant height by 13 to $33 \%$ and stem diameter by 5 to $25 \%$ and more leaves were retained by T3 plants at harvesting. T3 recorded higher fresh shoot (11.27\%) and dry shoot (14.98\%) as well as fresh root $(23.67 \%)$ and dry root $(22.77 \%)$ weights than T1 plants. Addition of AMF in treatments T2 and T3 promoted better nutrient uptake by aboveground and belowground biomasses particularly for $\mathrm{K}, \mathrm{Ca}$ and $\mathrm{Mg}$. T3 was superior in terms of the nutrient uptake for most nutrients. AMF used in $\mathrm{T} 3$ showed better results as the AMF spores were proven effective in promoting plant growth while AMF used in T2 were obtained from the field and untested. The findings of this study showed the potential of indigenous and non-indigenous AMF in promoting growth and nutrient uptake by terung asam plants.
\end{abstract}

Keywords: Arbuscular mycorrhizal fungi, biomass, growth, nutrient uptake, terung asam

Copyright : This is an open access article distributed under the terms of the CC-BY-NC-SA (Creative Commons Attribution-Non Commercial-Share Alike 4.0 International License) which permits unrestricted use, distribution, and reproduction in any medium, for non-commercial purposes, provided the original work of the author(s) is properly cited.

\section{INTRODUCTION}

Solanum lasiocarpum Dunal or locally known as terung asam is a golden yellow sour eggplant of the Solanaceae family that is native to Sarawak (Sman, 2017). Terung asam is also known as terung dayak, terung iban, terung berui and terung bulu in Sarawak (Lim, 2013). Terung asam is known as terung pasai in Brunei, cung bulu in Indonesia, khua kon in Laos, tabanburo in the Philippines, sinkade in Myammar, yongkuidi in Vietnam and muuk in Thailand (Razili et al., 2015). Terung asam can be found planted across the tropical region including India, Bangladesh, southern China, Indochina, Indonesia, Malaysia, New
Guinea, Solomon Islands, Thailand, and the Philippines (Heiser 1987; Mohanan \& George 2004).

Terung asam is commonly planted together with hill paddy as an intercrop plant by local farmers (Shariah, 2013) or grown on the edges of villages as weeds (Samuels, 2012). Terung asam is traditionally planted by seed, which normally germinates within seven days of sowing. Seeds can be directly planted in the field or germinated in polybags or seedling trays in a nursery for a period of 3 to 4 weeks before transplanting (Shariah et al., 2013). Terung asam prefers temperatures between 25 and $32{ }^{\circ} \mathrm{C}$ with an annual rainfall of $1,500 \mathrm{~mm}$ 
to $2,000 \mathrm{~mm}$ and relative humidity of $80 \%$ and 50 $75 \%$ shade for growth. Shariah et al. (2013) documented that the best soil for planting terung asam will be mineral or loamy soil with proper drainage and $\mathrm{pH}$ ranging from 5.5 to 6.8. Terung asam prefers soil with high content of organic matter and is known for its water-loving characteristics especially during fruiting.

Agronomically, terung asam forms flowers around 120 days after transplanting while fruits can be harvested after 132 to 141 days of transplanting (Shariah et al., 2013). Terung asam production can reach between 16 and 20 tonnes per hectare. In 2017, the price of the fruit was recorded between RM6 and RM10 per kg depending on the size and quality. Based on this price range, a net profit of RM134,313 to RM 204,323 can be generated from a production of 16,000 to 23,000 fruits from each harvest cycle sold at RM10 per kg (Sman, 2017).

Malaysia is covered by Ultisols and Oxisols soils that are highly weathered, acidic, and low in fertility for crop production. These soil groups are commonly found in the tropics and contain low amounts of organic matter thus making them insufficient in promoting plant growth (Shamshuddin \& Anda, 2012). The compost is normally applied to alleviate the infertility issue (Anda et al., 2010). Another approach is by applying mineral fertilisers, but this has increased the cost of crop production. Furthermore, the application of fertilisers more than the recommended limits is known to cause undesirable effects such as decreasing soil $\mathrm{pH}$, soil pollution, reduction in beneficial microbial activity, and even soil compaction. Therefore, alternative means must be sourced to reduce total dependency on mineral fertilisers to improve growth.

Arbuscular mycorrhizal fungi (AMF) are one of the many organisms that abundantly found in the environment, colonising almost all land communities including $80 \%$ of all vascular plants (Smith \& Read, 2010). These fungal symbionts are integral components of plant communities in both natural and agricultural ecosystems. Various authors have documented that associations between plant species and AMF are likely to increase the efficiency of fertiliser uptake and significantly enhance plant growth (height, leaf area, root volume, shoot, and root dry biomass) over uninoculated plants. Increased growth has been reported in various short-term and perennial crops inoculated with AMF. Some studies conclude that indigenous consortia are more effective at promoting plant growth in different species (Trejo et al., 2011; Carreón-Abud et al., 2015). Jansa et al. (2009) explained that the contrasting results that determined the final plant performance could be related to the dominant effect of one or more isolates of the complex AMF community. Meanwhile, Reyes-Tena et al. (2015) highlighted that the differences in the ability of indigenous $\mathrm{AMF}$ in promoting growth probably relied on the origin and diversity of AMF species that make up the inoculum.

To our knowledge, no studies have been conducted or reported on the roles of AMF in promoting growth and nutrient uptake by terung asam. Therefore, the objective of this study was to investigate the growth performance and nutrient uptake by terung asam plants inoculated with indigenous and non-indigenous AMF.

\section{MATERIALS \& METHODS}

\section{Seed Preparation}

Terung asam were purchased from a local wet market (Pasar Utama Bintulu), and the seeds were cleaned and dried using paper towels before sowing. Seeds were sowed in potting trays filled with potting media and were allowed to germinate in a greenhouse. The seedlings were considered ready for transplanting when two fully developed leaves had been produced. Only seedlings with similar heights and sizes were selected for the experiment to reduce biases.

\section{AMF Inocula and Soil}

The soil samples used in the isolation of indigenous AMF spores were sourced from the rhizospheres of trees growing in the disturbed man-made forest or known as the analogue forest (N 0312'33.4”, E $\left.113^{\circ} 04^{\prime} 58.2^{\prime \prime}\right)$. The site was selected based on the abundance of AMF found during the preliminary research conducted on the site. In the preliminary research, three AMF genera were found namely Glomus spp., Acaulospora spp., and Gigaspora spp. Soil samples were taken from three random spots at a depth of $5 \mathrm{~cm}$ to $20 \mathrm{~cm}$ for AMF spore isolation. This depth was selected as most of the root matrix of tropical trees are available at this depth and the root matrix is related to the sporulation of AMF. The soil samples were taken to the laboratory and air-dried. As for the nonindigenous AMF, the source (RHIZAgold) was 
Table 1. Concentration of nutrients in potting media prior to experiment

\begin{tabular}{lc}
\hline Nutrient Element & Concentration \\
\hline Total $\mathrm{N}(\%)$ & $0.17 \pm 0.01$ \\
Total $\mathrm{P}(\mathrm{mg} / \mathrm{kg})$ & $1,614.75 \pm 5.64$ \\
Available $\mathrm{P}(\mathrm{mg} / \mathrm{kg})$ & $74.59 \pm 3.34$ \\
Total K $(\mathrm{mg} / \mathrm{kg})$ & $747.50 \pm 6.29$ \\
Exchangeable K $(\mathrm{mg} / \mathrm{kg})$ & $16.95 \pm 0.87$ \\
Total Ca $(\mathrm{mg} / \mathrm{kg})$ & $905.00 \pm 6.45$ \\
Exchangeable Ca $(\mathrm{mg} / \mathrm{kg})$ & $36.70 \pm 5.05$ \\
Total $\mathrm{Mg}(\mathrm{mg} / \mathrm{kg})$ & $880.00 \pm 4.08$ \\
Exchangeable $\mathrm{Mg}(\mathrm{mg} / \mathrm{kg})$ & $17.92 \pm 0.69$ \\
\hline
\end{tabular}

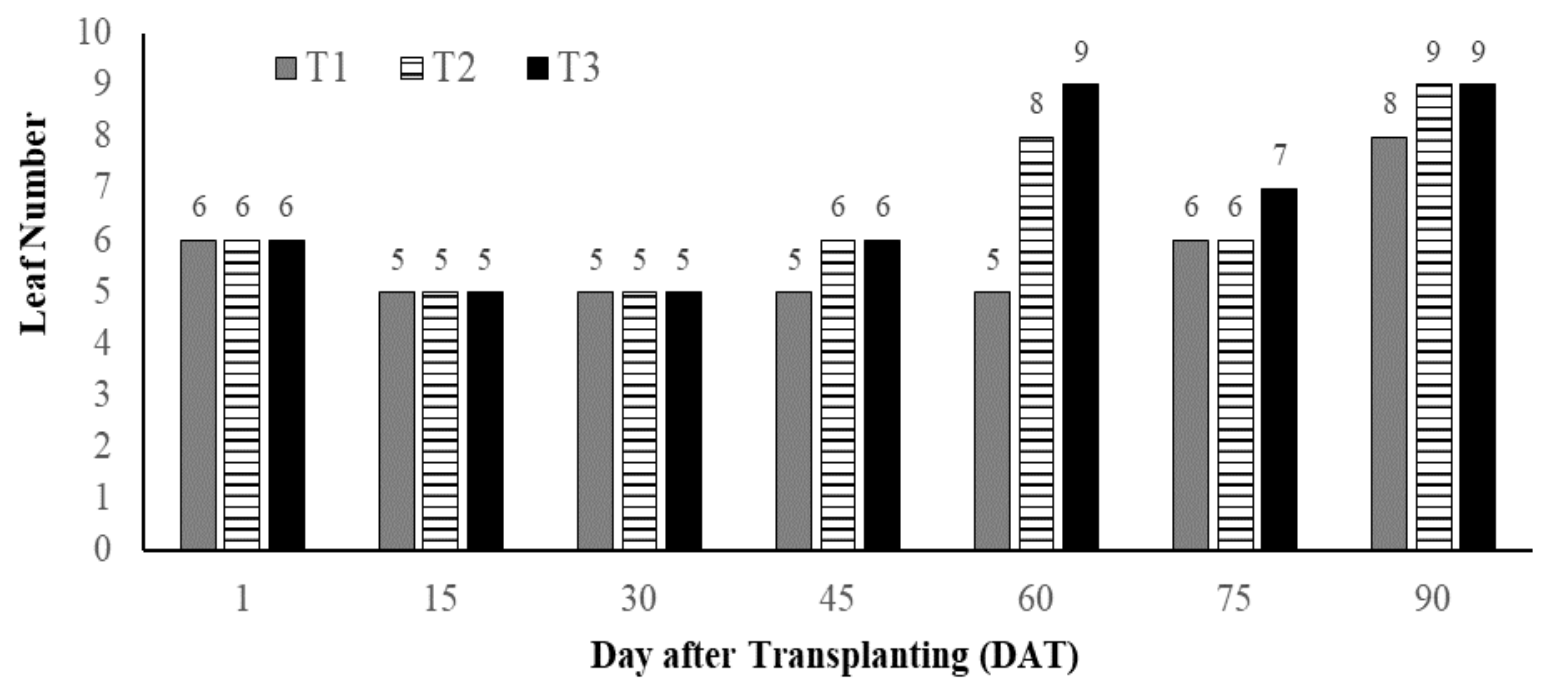

Figure 1. Leaf number of Terung asam plants recorded for a period of 90 days

purchased from a local agricultural product supplier shop in Bintulu, Sarawak. RHIZAgold is documented to contain a selected cocktail mixture of at least $12 \mathrm{AMF}$ species in its preparation with an effective concentration of 250-300 spores per 10 $\mathrm{g}$ of product.

Seedlings were ready for transplanting 30-days after germination. Approximately 200 AMF spores were added to each planting hole right before the seedling was planted to ensure that the AMF spores were in contact with the seedling root. Each pot (27 $\mathrm{cm} \times 22 \mathrm{~cm}$ ) was filled with soil of the Bekenu series (Table 1) obtained from an intensive agricultural site in the campus and adjusted to three-part subsoil and one-part sand before being planted with a single terung asam seedling.
The first day for growth measurement was conducted on the first day after transplanting (DAT).

\section{Plant Monitoring and Growth Parameters}

Watering is a critical factor that influences the plant growth. Each plant was provided with approximately $500 \mathrm{~mL}$ of water each day to maintain pot medium humidity at the optimum level to promote plant growth. Weeding activity was done routinely to get rid of weeds from growing inside the pot and minimise competition. Strict observation on plant growth, pest, and pathogen, as well as weed control, was conducted. Mechanical pest control method was adopted to avoid the usage of pesticide, weedicide, or 
herbicide that may harm the growth and development of terung asam plant and AMF.

Plant data including total leaf number per plant and plant height were recorded and measured every three days while plant diameter and chlorophyll content were measured every 15 days. Leaf number was counted manually while the plant height was measured using a measuring tape. The plant height is considered as the vertical measurement made from the leaf tip to the ground under natural conditions while plant diameter was measured using a digital calliper meter (Mitutoyo 500) and made at the widest part of the internode above the cotyledons (Wang et al, 2015). Meanwhile, a chlorophyll meter (Minolta SPAD 502) was used to determine the chlorophyll content.

\section{Plant Biomass}

Harvesting was conducted on 90 DAT. Plant biomass was separated into aboveground (plant parts above the cotyledon collar including leaves, stem, branches) and belowground biomass (all root parts below the cotyledon collar). Harvested roots were washed thoroughly using tap water to ensure that they were free from any soil debris. Each aboveground and belowground biomass sample was labeled and kept separately in a clear plastic bag and stored in a polystyrene box to retain moisture. Samples were brought to the laboratory and further cleaned then dried using tissue paper before being weighed to obtain the fresh weight using a benchtop balance (A\&D EK6100i). The aboveground and belowground biomass were separately inserted into paper envelopes $(33 \mathrm{~cm} \mathrm{x}$ $24 \mathrm{~cm}$ ) and dried continuously in an oven (Memmert UFB500) at $70{ }^{\circ} \mathrm{C}$ until a constant weight was achieved.

\section{Plant Nutrient Content}

Plant nutrient analyses were conducted to determine the content of $\mathrm{N}, \mathrm{P}, \mathrm{K}, \mathrm{Ca}$, and $\mathrm{Mg}$ of aboveground and belowground biomass. The dried sample was shredded into smaller sizes before the extraction. The Kjeldahl method (Bremner, 1965; Tan, 2005) was used to determine the total $\mathrm{N}$ content while the single dry ashing method (Cottenie, 1980) was adopted to extract total P, K, $\mathrm{Ca}$, and $\mathrm{Mg}$. Total $\mathrm{P}$ was determined using the UVVis spectrophotometer (Perkin Elmer Lambda 25) at $882 \mathrm{~nm}$ wavelength (Murphy \& Riley, 1962) while total $\mathrm{K}, \mathrm{Ca}$ and $\mathrm{Mg}$ were determined using the Atomic Absorption Spectrophotometer (AAS, Perkin Elmer AAnalyst 800). The nutrient uptake was determined for the two biomasses by multiplying the plant nutrient concentrations with the respective dry weights (Thangasamy \& Chavan, 2017).

\section{Experimental Design and Statistical Analysis}

The study consisted of three treatments (control, indigenous AMF, and non-indigenous AMF) and each treatment consisted of four subsamples which were replicated four times. Analysis of variance (ANOVA) was used to test the treatment effects. The means were compared using the Duncan's Multiple Range Test (DMRT) at $\mathrm{p} \leq 0.05$. The statistical analysis was conducted using the Statistical Analysis Software (SAS) Version 9.3. The correlation analysis was also included to see the relationship between plant roots and height growth.

\section{RESULTS}

\section{Height Growth}

Table 2 shows that for the first five measurements conducted, no significant difference was observed for terung asam supplied with additional AMF (T2, T3) or the control (T1). Significant differences in height growth began to show after 15 DAT. From 15 to 27 DAT, height growth of plants inoculated with non-indigenous AMF (T3) was found to be significantly different from the control (T1) and those added with indigenous AMF from the disturbed man-made forest (T2). From 30 to 45 DAT, T2 and T3 further showed their dominance over T1. This pattern was continuously observed in the following three measurements (48 to 54 DAT) where $\mathrm{T} 1$ were found to be significantly inferior to $\mathrm{T} 2$ and $\mathrm{T} 3$ which among themselves were not significantly different in terms of height growth. As measurements continued from 57 to 81 DAT, T3 further showed their superiority in height growth by being significantly taller than $\mathrm{T} 1$ and $\mathrm{T} 2$. $\mathrm{T} 1$ gave the lowest height growth among the three treatments. For the last three days of height measurement, T3 showed dominance in height growth over T1. Terung asam plants provided with additional indigenous and non-indigenous AMF exhibited $13 \%$ to $33 \%$ higher height growth than the control plants. 
Table 2. Mean heights of terung asam plants as affected by treatments measured at three days interval for a period of 90 days

\begin{tabular}{|c|c|c|c|}
\hline \multirow{2}{*}{ DAT } & \multicolumn{3}{|c|}{ Height growth $(\mathrm{cm})$ by treatment } \\
\hline & $\mathbf{T 1}$ & $\mathbf{T 2}$ & $\mathbf{T 4}$ \\
\hline 1 & $1.99^{a} \pm 0.07$ & $2.09^{\mathrm{a}} \pm 0.07$ & $1.99^{a} \pm 0.12$ \\
\hline 3 & $2.41^{\mathrm{a}} \pm 0.09$ & $2.56^{\mathrm{a}} \pm 0.06$ & $2.38^{\mathrm{a}} \pm 0.08$ \\
\hline 6 & $2.73^{\mathrm{a}} \pm 0.09$ & $2.89^{\mathrm{a}} \pm 0.07$ & $2.70^{\mathrm{a}} \pm 0.14$ \\
\hline 9 & $3.19^{\mathrm{a}} \pm 0.07$ & $3.31^{\mathrm{a}} \pm 0.11$ & $3.29^{\mathrm{a}} \pm 0.18$ \\
\hline 12 & $4.01^{\mathrm{a}} \pm 0.16$ & $4.01^{\mathrm{a}} \pm 0.15$ & $4.45^{\mathrm{a}} \pm 0.16$ \\
\hline 15 & $4.48^{\mathrm{b}} \pm 0.16$ & $4.36^{\mathrm{b}} \pm 0.14$ & $5.04^{\mathrm{a}} \pm 0.15$ \\
\hline 18 & $5.03^{\mathrm{b}} \pm 0.17$ & $4.82^{b} \pm 0.16$ & $5.83^{\mathrm{a}} \pm 0.14$ \\
\hline 21 & $5.85^{\mathrm{c}} \pm 0.18$ & $5.76^{\mathrm{bc}} \pm 0.21$ & $6.94^{\mathrm{a}} \pm 0.23$ \\
\hline 24 & $6.84^{\mathrm{b}} \pm 0.20$ & $7.01^{b} \pm 0.29$ & $8.23^{\mathrm{a}} \pm 0.51$ \\
\hline 27 & $7.91^{\mathrm{b}} \pm 0.26$ & $8.19^{b} \pm 0.39$ & $9.46^{\mathrm{a}} \pm 0.69$ \\
\hline 30 & $9.46^{\mathrm{b}} \pm 0.38$ & $10.38^{\mathrm{ab}} \pm 0.59$ & $11.38^{\mathrm{a}} \pm 0.85$ \\
\hline 33 & $11.36^{\mathrm{a}} \pm 0.49$ & $12.29^{\mathrm{a}} \pm 0.64$ & $13.33^{\mathrm{a}} \pm 0.85$ \\
\hline 36 & $13.19^{b} \pm 0.56$ & $14.34^{\mathrm{ab}} \pm 0.81$ & $16.00^{\mathrm{a}} \pm 1.17$ \\
\hline 39 & $15.09^{c} \pm 0.62$ & $17.22^{\mathrm{bc}} \pm 0.78$ & $19.85^{\mathrm{a}} \pm 0.93$ \\
\hline 42 & $16.83^{b} \pm 0.75$ & $19.29^{\mathrm{ab}} \pm 0.99$ & $21.88^{\mathrm{a}} \pm 1.08$ \\
\hline 45 & $18.78^{b} \pm 0.85$ & $21.61^{\mathrm{ab}} \pm 1.06$ & $24.41^{\mathrm{a}} \pm 1.35$ \\
\hline 48 & $20.65^{\mathrm{b}} \pm 1.04$ & $24.38^{\mathrm{a}} \pm 1.21$ & $27.38^{\mathrm{a}} \pm 1.43$ \\
\hline 51 & $22.41^{\mathrm{b}} \pm 1.05$ & $26.94^{\mathrm{a}} \pm 1.18$ & $29.56^{\mathrm{a}} \pm 1.85$ \\
\hline 54 & $24.24^{\mathrm{b}} \pm 1.26$ & $29.29^{a} \pm 1.26$ & $31.73^{\mathrm{a}} \pm 2.04$ \\
\hline 57 & $25.38^{\mathrm{c}} \pm 1.26$ & $31.13^{\mathrm{b}} \pm 1.41$ & $35.63^{\mathrm{a}} \pm 1.82$ \\
\hline 60 & $27.00^{c} \pm 1.32$ & $33.63^{b} \pm 1.67$ & $39.75^{\mathrm{a}} \pm 1.73$ \\
\hline 63 & $28.88^{c} \pm 1.35$ & $35.44^{\mathrm{b}} \pm 1.73$ & $41.00^{\mathrm{a}} \pm 1.54$ \\
\hline 66 & $30.47^{\mathrm{c}} \pm 1.38$ & $37.31^{\mathrm{b}} \pm 1.88$ & $43.75^{\mathrm{a}} \pm 1.69$ \\
\hline 72 & $32.14^{\mathrm{c}} \pm 1.58$ & $39.19^{b} \pm 1.93$ & $46.00^{\mathrm{a}} \pm 1.81$ \\
\hline 75 & $34.56^{\mathrm{c}} \pm 1.74$ & $41.19^{b} \pm 1.93$ & $48.25^{\mathrm{a}} \pm 1.88$ \\
\hline 78 & $36.81^{\mathrm{c}} \pm 1.81$ & $42.94^{\mathrm{b}} \pm 1.95$ & $49.25^{\mathrm{a}} \pm 1.71$ \\
\hline 81 & $38.31^{\mathrm{c}} \pm 1.69$ & $44.50^{\mathrm{b}} \pm 1.91$ & $50.88^{a} \pm 1.78$ \\
\hline 84 & $42.88^{b} \pm 1.98$ & $48.13^{\mathrm{ab}} \pm 1.90$ & $53.43^{\mathrm{a}} \pm 2.49$ \\
\hline 87 & $43.62^{b} \pm 2.13$ & $50.69^{\mathrm{ab}} \pm 2.43$ & $54.33^{\mathrm{a}} \pm 3.14$ \\
\hline 90 & $47.31^{b} \pm 2.07$ & $51.60^{\mathrm{ab}} \pm 2.21$ & $56.00^{\mathrm{a}} \pm 3.02$ \\
\hline
\end{tabular}

Note: Different letters within a row indicate a significant difference between means \pm standard error using DMRT at $\mathrm{p} \leq 0.05$ 
Table 3. Diameter of terung asam plants as affected by treatments measured at an interval of 15 days for a period of 90 days

\begin{tabular}{cccc}
\hline \multirow{2}{*}{ DAT } & \multicolumn{3}{c}{ Diameter growth $(\mathbf{m m})$ by treatment } \\
\cline { 2 - 4 } & $\mathbf{T 1}$ & $\mathbf{T 3}$ & $\mathbf{T 4}$ \\
\hline 1 & $3.32^{\mathrm{a}} \pm 0.08$ & $3.40^{\mathrm{a}} \pm 0.15$ & $3.69^{\mathrm{a}} \pm 0.05$ \\
15 & $4.79^{\mathrm{b}} \pm 0.03$ & $4.91^{\mathrm{a}} \pm 0.14$ & $5.56^{\mathrm{a}} \pm 0.06$ \\
30 & $6.57^{\mathrm{b}} \pm 0.12$ & $6.32^{\mathrm{b}} \pm 0.11$ & $7.16^{\mathrm{a}} \pm 0.14$ \\
45 & $7.67^{\mathrm{b}} \pm 0.22$ & $7.74^{\mathrm{b}} \pm 0.17$ & $8.91^{\mathrm{a}} \pm 0.23$ \\
60 & $8.44^{\mathrm{b}} \pm 0.15$ & $8.91^{\mathrm{b}} \pm 0.27$ & $10.20^{\mathrm{a}} \pm 0.28$ \\
75 & $9.00^{\mathrm{c}} \pm 0.09$ & $9.84^{\mathrm{b}} \pm 0.22$ & $11.55^{\mathrm{a}} \pm 0.35$ \\
90 & $9.55^{\mathrm{d}} \pm 0.08$ & $10.62^{\mathrm{b}} \pm 0.13$ & $12.75^{\mathrm{a}} \pm 0.16$ \\
\hline
\end{tabular}

Note: Different letters within a row indicate a significant difference between means \pm standard error using DMRT at $\mathrm{p} \leq 0.05$

Table 4. Fresh shoot and root weights and flowering phase affected by AMF as observed in terung asam plants

\begin{tabular}{lccc}
\hline \multirow{2}{*}{ Parameter } & \multicolumn{3}{c}{ Treatment } \\
\cline { 2 - 4 } & $\mathbf{T 1}$ & $\mathbf{T 2}$ & $\mathbf{T 3}$ \\
\hline Fresh shoot $(\mathrm{g})$ & $83.32^{\mathrm{c}} \pm 0.33$ & $92.40^{\mathrm{b}} \pm 0.15$ & $93.90^{\mathrm{a}} \pm 0.42$ \\
Dry shoot $(\mathrm{g})$ & $10.95^{\mathrm{b}} \pm 0.22$ & $12.47^{\mathrm{a}} \pm 0.19$ & $12.88^{\mathrm{a}} \pm 0.17$ \\
Fresh root $(\mathrm{g})$ & $45.80^{\mathrm{b}} \pm 0.44$ & $59.58^{\mathrm{a}} \pm 0.18$ & $60.00^{\mathrm{a}} \pm 0.26$ \\
Dry root $(\mathrm{g})$ & $10.24^{\mathrm{b}} \pm 0.16$ & $13.42^{\mathrm{a}} \pm 0.23$ & $13.26^{\mathrm{a}} \pm 0.25$ \\
Flowering & Yes & Yes & Yes \\
\hline
\end{tabular}

Note: Different letters within a row indicate a significant difference between means \pm standard error using DMRT at $\mathrm{p} \leq 0.05$

Table 5. Nutrient uptake by aboveground biomass recorded at the end of the experiment

\begin{tabular}{lccc}
\hline \multirow{2}{*}{ Element } & \multicolumn{3}{c}{ Nutrient uptake by aboveground biomass } \\
\cline { 2 - 4 } & T1 & T2 & T3 \\
\hline $\mathrm{N}(\mathrm{mg} /$ plant $)$ & $48.50^{\mathrm{a}} \pm 0.61$ & $57.96^{\mathrm{a}} \pm 4.55$ & $48.00^{\mathrm{a}} \pm 3.51$ \\
$\mathrm{P}(\mathrm{mg} /$ plant $)$ & $23.06^{\mathrm{a}} \pm 4.90$ & $19.64^{\mathrm{a}} \pm 1.08$ & $25.09^{\mathrm{a}} \pm 0.18$ \\
$\mathrm{~K}(\mathrm{mg} /$ plant $)$ & $3.59^{\mathrm{b}} \pm 3.65$ & $8.27^{\mathrm{a}} \pm 0.27$ & $8.80^{\mathrm{a}} \pm 0.29$ \\
$\mathrm{Ca}(\mathrm{mg} /$ plant $)$ & $6.61^{\mathrm{c}} \pm 0.33$ & $16.81^{\mathrm{b}} \pm 0.90$ & $21.13^{\mathrm{a}} \pm 0.91$ \\
Mg (mg/plant) & $4.08^{\mathrm{b}} \pm 0.25$ & $6.31^{\mathrm{a}} \pm 0.11$ & $6.67^{\mathrm{a}} \pm 0.20$ \\
\hline
\end{tabular}

Note: Different letters within a row indicate significant difference between means \pm standard error using DMRT at $\mathrm{p} \leq 0.05$ 
Table 6. Nutrient uptake by belowground biomass recorded at the end of the experiment

\begin{tabular}{lccc}
\hline \multirow{2}{*}{ Element } & \multicolumn{3}{c}{ Nutrient uptake by below ground biomass } \\
\cline { 2 - 4 } & $\mathbf{T} 1$ & T2 & T3 \\
\hline $\mathrm{N}(\mathrm{mg} /$ plant $)$ & $2.72^{\mathrm{b}} \pm 0.28$ & $7.59^{\mathrm{a}} \pm 1.02$ & $5.50^{\mathrm{a}} \pm 0.65$ \\
$\mathrm{P}(\mathrm{mg} / \mathrm{plant})$ & $11.65^{\mathrm{a}} \pm 0.72$ & $15.30^{\mathrm{a}} \pm 0.40$ & $16.88^{\mathrm{a}} \pm 2.70$ \\
$\mathrm{~K}$ (mg/plant) & $3.50^{\mathrm{c}} \pm 0.37$ & $9.16^{\mathrm{b}} \pm 0.21$ & $10.41^{\mathrm{a}} \pm 0.55$ \\
$\mathrm{Ca}$ (mg/plant) & $6.26^{\mathrm{c}} \pm 0.46$ & $17.17^{\mathrm{b}} \pm 0.99$ & $22.24^{\mathrm{a}} \pm 0.59$ \\
$\mathrm{Mg}$ (mg/plant) & $3.84^{\mathrm{c}} \pm 0.27$ & $6.86^{\mathrm{b}} \pm 0.09$ & $7.37^{\mathrm{a}} \pm 0.16$
\end{tabular}

Note: Different letters within a row indicate significant difference between means \pm standard error using DMRT at $\mathrm{p} \leq 0.05$

\section{Diameter growth}

Table 3 shows the growth of stem diameter for 90 days. Terung asam plants added with nonindigenous AMF (T3) showed better diameter growth than the control plants (T1) as early as 15 DAT. All plants with added AMF (T2 and T3) were not significantly different from one another during this period. Terung asam in T1 showed lower diameter growth than plants supplied with indigenous and non-indigenous AMF. T3 showed higher diameter growth than the other two treatments after $30 \mathrm{DAT}$ and this pattern continued until the end of the experiment. T3 continuously showed dominance over $\mathrm{T} 1$ and $\mathrm{T} 2$, with $\mathrm{T} 1$ always showing inferiority in terms of diameter growth. All diameter growth became significantly different at 75 DAT whereby plants inoculated with AMF became more prominent than the control plants. Plants inoculated with indigenous or nonindigenous AMF showed better diameter growth by $5 \%$ up to $25 \%$ than the control plants.

\section{Plant biomass and leaf number}

Table 4 displays the mean fresh root weight, mean fresh shoot weight and the ability of the plant under each treatment to reach the flowering stage. The fresh weights for the treatments varied from 83.32 $\mathrm{g}$ to $93.90 \mathrm{~g}$ for the shoots and $45.80 \mathrm{~g}$ to $60.00 \mathrm{~g}$ for the roots. Meanwhile, the dry weights of plants for the treatments ranged from $10.95 \mathrm{~g}$ to $12.88 \mathrm{~g}$ for the shoots and $10.24 \mathrm{~g}$ to $13.26 \mathrm{~g}$ for the roots. Generally, higher fresh and dry shoot and root weights were observed for plants with indigenous and non-indigenous AMF than the control plants (T1). A difference of up to $11.27 \%$ for fresh shoot weight and $14.98 \%$ for dry shoot weight were observed between plants with non-indigenous AMF (T3) and the control plants (T1). Plants inoculated with additional AMF (T2 and T3) recorded heavier shoot and root weights than the control plants (T1). Similarly, plants with nonindigenous AMF (T3) recorded higher fresh root weight with a difference of $23.67 \%$ than $\mathrm{T} 1$ while $22.77 \%$ was documented for dry root weight for the same treatment. All plants began to flower at 90 DAT.

Leaf numbers in all treatments began to show some significant differences after 45 DAT (Figure 1). Terung asam plants treated with indigenous AMF (T2) and with non-indigenous AMF (T3) were found to have more leaves (nine leaves) compared to plants without additional AMF (T1). Terung asam plants provided with additional nonindigenous AMF (T3) were found better in retaining their leaves than other treatments.

\section{Plant nutrient uptake}

The nutrient uptake by the plant based on the aboveground biomass for the treatments was significantly different for all treatments except for total $\mathrm{N}$ and $\mathrm{P}$ (Table 5). T2 and T3 treated plants showed significantly higher nutrient values compared to $\mathrm{T} 1$ for total $\mathrm{K}, \mathrm{Ca}$, and $\mathrm{Mg}$. The total $\mathrm{K}$ uptake was $3.59 \mathrm{mg} /$ plant, $8.27 \mathrm{mg} /$ plant in T1 and $8.80 \mathrm{mg} / \mathrm{plant}$ in T3, respectively. As for total $\mathrm{Ca}$, all treatments showed significant differences for nutrient uptake with T3 plants showing the highest uptake $(21.13 \mathrm{mg} / \mathrm{plant})$ followed by T2 $(16.0 \mathrm{mg} / \mathrm{plant})$ and $\mathrm{T} 1 \mathrm{with}$ the lowest $(6.61$ $\mathrm{mg} /$ plant) uptake value. Meanwhile, total $\mathrm{Mg}$ values were recorded between $4.08 \mathrm{mg} / \mathrm{pot}$ in $\mathrm{T} 1$ and $6.67 \mathrm{mg} / \mathrm{plant}$ in T3 with values recorded 
for T2 and T3 not significantly different.

As for nutrient uptake by belowground biomass (Table 6), T2 recorded significantly higher uptake (7.59 mg/plant) for total $\mathrm{N}$ than the rest of the treatments with values ranging from $2.72 \mathrm{mg} / \mathrm{plant}$ in T1 to $7.59 \mathrm{mg} / \mathrm{plant}$ in T3. Only T2 plants ( 23.52 $\mathrm{mg} / \mathrm{plant}$ ) showed better uptake than T1 plants $(11.65 \%)$ for total P. As for total K, Ca and $\mathrm{Mg}$ uptakes, all treatments were superior to $\mathrm{T} 1$ which exhibited lower uptakes for all three elements. The values for nutrient uptake ranged from 3.50 $\mathrm{mg} /$ plant (T1) to $10.41 \mathrm{mg} /$ plant (T3) for total K, $6.26 \mathrm{mg} / \mathrm{plant}$ (T1) to $22.24 \mathrm{mg} / \mathrm{plant}$ (T3) for total $\mathrm{Ca}$, and $3.84 \mathrm{mg} /$ plant (T1) to $7.37 \mathrm{mg} /$ plant (T3) for total $\mathrm{Mg}$.

The addition of AMF spores in treatments $\mathrm{T} 2$ and $\mathrm{T} 3$ promoted better nutrient uptake in both aboveground and belowground plant biomass especially for nutrients such as $\mathrm{K}, \mathrm{Ca}$, and $\mathrm{Mg}$ than $\mathrm{T} 1$. As for aboveground biomass, treatment T3 was found to be superior to other treatments in terms of nutrient uptake for most nutrient elements. Nutrient uptakes by $\mathrm{T} 3$ aboveground biomass as compared to other treatments were greater by $28.29 \%$ to $59.20 \%$ for $\mathrm{K}, 20.44 \%$ to $68.71 \%$ for $\mathrm{Ca}$, and $10.49 \%$ to $38.83 \%$ for $\mathrm{Mg}$. On the other hand, comparison with other treatments observed that nutrients uptake by $\mathrm{T} 3$ for belowground biomass were higher by $12.00 \%$ to $66.38 \%$ for $\mathrm{K}, 22.62 \%$ to $71.31 \%$ for $\mathrm{Ca}$, and $6.92 \%$ to $47.90 \%$ for $\mathrm{Mg}$.

\section{DISCUSSION}

Significant differences were observed in the physical growth (height and stem diameter) of terung asam. Generally, terung asam plants with additional AMF showed better height growth than the control. Terung asam treated with the indigenous and non-indigenous AMF grew 13\% to $33 \%$ higher than plants without any additional AMF provided. Meanwhile, plants inoculated with indigenous and non-indigenous AMF showed better diameter growth by $5 \%$ up to $25 \%$ than plants without any addition of AMF. Song (2017) noted the importance of strong root growth in ensuring proper growth and development of the shoot as the root system connects the soil and plant shoot with regards to material exchange between the two. Terung asam plants treated with nonindigenous AMF showed superior diameter growth as well as the overall aboveground biomass. Sun et al. (2019) documented that stem diameter is responsible to supply developing leaves with resources for growth besides its role in dictating the flow of photosynthates from the mature leaves to other parts of the plants. It is believed that the higher aboveground biomass shown by terung asam plants in T3 may be closely related to the better stem diameter growth of the plant as predicted by Paul et al. (2016).

The findings of this research agree with the report by Eo \& Eom (2009) on some vegetable plants and $\mathrm{Lu} \& \mathrm{Wu}$ (2017) on white clover (Trifolium repens) where plants inoculated with AMF showed higher biomass increment. Hoeksema et al. (2010) reported that plants colonised by AMF grew larger than those without AMF. A similar conclusion was documented by Ortas (2010) where cucumber plants inoculated with AMF resulted in better plant growth. Better growth observed in AMF plants may be an indication that AMF inoculated plants, through the development of extraradical hyphae, can absorb more water and nutrients from the soil (Chen et al., 2016). Cagras et al. (2000) also reported that mycorrhizal inoculation significantly increased the fresh and dry weight of leaf and shoot, and root biomass of cucumber plants.

In the present study, the nutrient analysis conducted on the potting media (Table 1) before the experiment concluded that the soil was nutrient deficient with low available P, very low exchangeable $\mathrm{K}$ and exchangeable $\mathrm{Ca}$, and low exchangeable $\mathrm{Mg}$, which are characteristics of the Bekenu Series. Teste et al. (2016) noted deficiency in soil $\mathrm{P}$ can cause plants to have low biomass increment of extraradical hyphae in the acquisition of $\mathrm{P}$ despite a high AMF root colonisation thus affecting the overall plant growth in Lycopersicon esculentum (tomato).

Therefore, it was suggested that AMF inoculation and fertilisation are necessary to achieve sufficient growth in areas where nutrient availability is limited. Schreiner (2007) noted that grapevines, which are highly dependent on AMF to acquire $\mathrm{P}$ and other nutrients when planted in $\mathrm{P}$ deficient soils, become less dependent when grown in fertile soils. Subhashini (2016) on the other hand reported a significant increase in plant biomass of Nicotiana tabacum L. when NPK fertilisers and AMF were added to plants planted in a soil with poor nutrients availability. 
The symbiotic relationship between host plants and AMF is complex. The taxa of the AMF used in the present study were not of the same origin but a mixture of different AMF species. In the present study, although the indigenous mycorrhiza applied in T2 was sourced from a disturbed forest, the diversity of mycorrhiza may still be kept intact and high as the site was planted with perennial tree species with no further disturbance after the establishment until present. Terung asam plants inoculated with non-indigenous AMF were found to show better growth than plants inoculated with indigenous AMF for both height and diameter growth. AMF inoculation has been reported to promote plant growth, but it is not always the case. Some isolates of AMF have been reported to decrease the biomass of host plants (Smith \& Read, 2010). AMF symbiosis could have been found to differ according to the genotypes involved, the host plants as well as the combination of AMF (Munkvold et al., 2004).

There have been various reports regarding the effectiveness of indigenous and non-indigenous AMF in promoting the growth of host plants. Pellegrino et al. (2011) noted that indigenous AMF inoculum was more effective than exotic fungal isolate in improving growth and nutrient absorption by Trifolium alexandrinum. Ziane et al. (2017) reported that indigenous fungal isolates and commercial AMF inoculum failed to give any significant difference in stimulating the growth of tomatoes. Similarly, Ortas \& Ustuner (2014) documented that inoculation with an indigenous and commercial inoculum of AMF gave the same effect on Citrus aurantium with native spores having the same effect as a commercial inoculum. Meanwhile, Schreiner (2007) concluded that indigenous AMF is not necessarily better in promoting growth and nutrient absorption which is aligned with the findings of this research.

According to Meyer (2004), AMF may significantly improve the growth of host plants during the early stage of plant establishment but van der Heijden et al. (2002) highlighted the influence of host plants and environmental conditions in controlling the efficiency of AMF. Environmental factors that can influence AMF colonisation include soil conditions such as the nutritional (Nouri et al., 2014) and physical characteristics of soil (Posada et al., 2008). Goss et al. (2017) highlighted the impact of past cultural or management practices in influencing mycorrhizal colonisation. Thus, the source of indigenous AMF applied may have influenced the effectiveness of AMF in promoting the growth of $\mathrm{T} 2$ plants.

Liu et al. (2002) documented the ability of AMF in increasing $\mathrm{K}, \mathrm{Ca}$, and $\mathrm{Mg}$ uptake in soil when the concentration of soil P is low. Similarly, Cruz et al. (2017) noted that AMF inoculation will increase the uptake of $\mathrm{K}, \mathrm{Ca}$, and $\mathrm{Mg}$ besides $\mathrm{P}$ and $\mathrm{N}$ content. According to Liu et al. (2002), lower K, $\mathrm{Ca}$ and $\mathrm{Mg}$ may be due to the improvement in the exploitation of soil by the AMF either through the increment of the absorption area by the hyphae or shortening of the travel distance required by nutrients to reach the roots. Kothari et al. (1990) reported that AMF relationships could increase $\mathrm{K}$, $\mathrm{Ca}$, and $\mathrm{Mg}$ uptake by increasing water uptake by speeding up the mass flow of nutrients in the soil to reach the root system.

It was also noted that the effects of AMF on plants can be influenced by factors such as soil conditions and AMF inoculum. The amount of $\mathrm{P}$ in the potting medium used in the study was not controlled as the soil was collected from an agricultural field. The source of AMF inoculum added to $\mathrm{T} 2$ was from a disturbed forest thus the possibilities that environmental conditions, such as variation in soil $\mathrm{P}$, may have influenced the diversity of AMF taxa causing differences in response by the host plants (Eo \& Eom, 2009). Goss et al. (2017) also highlighted the impact of past cultural practices that can influence mycorrhizal colonisation.

\section{CONCLUSION}

Terung asam plants treated with indigenous (T2) and non-indigenous (T3) AMF spores showed better growth performance than the control plants (T1). Incorporation of AMF in modern agricultural practice is important especially in practicing good and healthy farming. It should be encouraged and exploited to reduce further dependency on chemical fertilisers that can cause detrimental effects on the environment besides the annual rise in fertiliser prices. Search for local sources or indigenous AMF inoculum especially those with host specificity is of high importance as it can further help in reducing crop production costs. Exploration and testing of indigenous AMF inoculum such as the one used in $\mathrm{T} 2$ are very much recommended. Future research should explore more indigenous AMF and study the contribution of other microorganisms that complement AMF in enhancing nutrient availability in soil and uptake. 


\section{ACKNOWLEDGEMENT}

We would like to thank Universiti Putra Malaysia Bintulu Sarawak Campus for the permission to use its facilities to conduct this research. We would also like to acknowledge that this research was financially supported by the Fundamental Research Grant Scheme (FRGS/2/2013/SG03/UPM/02/3) of the Ministry of Higher Education Malaysia.

\section{REFERENCES}

Anda, M., Shamshuddin, J., Fauziah, C. I. \& Syed Omar, S. R. (2010). Increasing the organic matter content of an Oxisol using rice husk compost: changes in decomposition and its chemistry. Soil Science Society of America Journal, 74(4): 11671180 .

Bremner, J.M. (1965). Total Nitrogen. In: Black, C.A., Evan, D.D., Ensminger, L.E., White, J.L., Clark, F.E., and Dinauer, R.D. (eds.). Method of Soil Analysis. Madison, Wisconsin. American Society of Agronomy.

Cagras, S., Sari, N. \& Ortas, İ. (2000). The effects of vesicular-arbuscular mycorrhizae on the plant growth and nutrient uptake of cucumber. Turkish Journal of Agriculture and Forestry, 24(5): 571578.

Carreón-Abud, Y., Vega-Fraga, M. \& Gavito, M. E. (2015). Interaction of arbuscular mycorrhizal inoculants and chicken manure in avocado rootstock production. Journal of Soil Science and Plant Nutrition, 15(4): 867-881.

Chen, S., Xing, Y., Wang, T., Zhang, Q., Yu, W., Fang, K., Newhouse, A. E., McGuigan, L. D., Stewart, K. R., Maynard, C. A. \& Powell, W. A. (2016). Ectomycorrhizae symbiosis in Castanea mollissima improves phosphate acquisition through activating gene expression and $\mathrm{H}+$ efflux. Scientia Horticulturae, 210: 99-107.

Cottenie, A. (1980). Soil testing and plant testing as a basis for fertilizer recommendation. FAO Soil Bulletin, 38: 70-73.

Cruz, A.F., de Oliveira, B.F. \& de Carvalho Pires, M. (2017). Optimum level of nitrogen and phosphorus to achieve better papaya (Carica papaya var. Solo) seedlings growth and mycorrhizal colonization. International Journal of Fruit Science, 17(3): 259268.
Eo, J.K. \& Eom, A.H. (2009). Differential growth response of various crop species to arbuscular mycorrhizal inoculation. Mycobiology, 37(1): 72-76.

Eo, J.K. \& Eom, A.H. (2018). Diversity of foliar endophytic fungi inhabiting coniferous trees in Korea. The Korean Journal of Mycology, 46(3): 205211.

Goss, M. J., Carvalho, M. \& Brito, I. (2017). Functional diversity of mycorrhiza and sustainable agriculture: Management to overcome biotic and abiotic stresses. Cambridge, MA, USA, Academic Press.

Heiser, C.B. (1987). Origins of Solanum lasiocarpum and $S$. repandum. American Journal of Botany, 74(7): 1045-1048.

Hoeksema, J., Chaudhary, B., Gehring, C., Johnson, N., Karst, J., Koide, R., Pringle, A., Zabinski, C., Bever, J., Moore, J., Wilson, G., Klironomos, J. \& Umbanhowar, J. (2010). A meta-analysis of contextdependency in plant response to inoculation with mycorrhizal fungi. Ecology Letters, 13: 394-407.

Jansa, J., Oberholzer, H.R. \& Egli, S. (2009). Environmental determinants of the arbuscular mycorrhizal fungal infectivity of Swiss agricultural soils. European Journal of Soil Biology, 45(5-6): 400-408.

Kothari, S.K., Marschner, H. \& George, E. (1990). Effect of VA mycorrhizal fungi and rhizosphere microorganisms on root and shoot morphology, growth and water relations in maize. New Phytologist, 116(2): 303-311.

Lim, T.K. (2013) Solanum lasiocarpum. Edible medicinal and non-medicinal plants. Springer, Dordrecht. pp. 333-335.

Liu, A., Hamel, C., Elmi, A., Costa, C., Ma, B. \& Smith, D.L. (2002). Concentrations of $\mathrm{K}, \mathrm{Ca}$ and $\mathrm{Mg}$ in maize colonized by arbuscular mycorrhizal fungi under field conditions. Canadian Journal of Soil Science, 82(3): 272-278.

Lu, L.H. \& Wu, Q.S. (2017). Mycorrhizas promote plant growth, root morphology and chlorophyll production in white clover. Biotechnology, 16: 34-39.

Meyer, J. (2004). Use of endotrophic mycorrhizal and soil microorganisms in vegetation establishment on mineral green roof substrates. In Greening Rooftops for Sustainable Communities 2004 Conference Proceedings, Portland. 
Mohanan, N.N. \& George, K.V. (2004). Cultivated crops and their wild relatives of Kerala State. In Proceedings of the National Seminar on Biodiversity Conservation and Environment Management, Catholicate College, Pathanamthitta, Kerala, India. Pp. 82-87.

Munkvold, L., Kjøller, R., Vestberg, M., Rosendahl, S. \& Jakobsen, I. (2004). High functional diversity within species of arbuscular mycorrhizal fungi. New Phytologist, 164(2): 357-364.

Murphy, J. \& Riley, J.P. (1962). A modified single solution method for the determination of phosphate in natural waters. Analytical Chemistry Acta, 27: 3136.

Nouri, E., Breuillin-Sessoms, F., Feller, U. \& Reinhardt, D. (2014). Phosphorus and nitrogen regulate arbuscular mycorrhizal symbiosis in Petunia hybrida. PloS One, 9(3): e90841.

Ortas, I. \& Ustuner, O. (2014). The effects of single species, dual species and indigenous mycorrhiza inoculation on citrus growth and nutrient uptake. European Journal of Soil Biology, 63: 64-69.

Paul, K.I., Roxburgh, S.H., Chave, J., England, J.R., Zerihun, A., Specht, A., Lewis, T., Bennett, L.T., Baker, T.G., Adams, M.A. \& Huxtable, D. (2016).

Testing the generality of above - ground biomass allometry across plant functional types at the continent scale. Global Change Biology, 22(6): 2106-2124.

Pellegrino, E., Bedini, S., Avio, L., Bonari, E. \& Giovannetti, M. (2011). Field inoculation effectiveness of native and exotic arbuscular mycorrhizal fungi in a Mediterranean agricultural soil. Soil Biology and Biochemistry, 43(2): 367-376.

Posada, R.H., Franco, L.A., Ramos, C., Plazas, L.S., Suárez, J.C. \& Álvarez, F. (2008). Effect of physical, chemical and environmental characteristics on arbuscular mycorrhizal fungi in Brachiaria decumbens (Stapf) pastures. Journal of Applied Microbiology, 104(1): 132-140.

Razili, R.M., Umar, S. \& Sallehuddin, R. (2015). Quality product from terung asam (Solanum Iasiocarpum Dunal): A popular indigenous fruitvegetable of Sarawak, Malaysia. Acta Horticulturae, 1088: 569-572.

Reyes-Tena, A., López-Pérez, L., Quiñones-Aguilar, E.E. \& Rincón-Enríquez, G. (2015). Evaluation of arbuscular mycorrhizal consortia in the plant growth of corn, chili and bean plants. Revista Biological, 17: $35-42$.
Samuels, J. (2012). Genetically engineered Bt. Brinjal and the implications for plant biodiversity. Cornwall, United Kingdom: Novel Solanaceae Crops Project.

Schreiner, R.P. (2007). Effects of native and non-native arbuscular mycorrhizal fungi on growth and nutrient uptake of 'Pinot noir' (Vitis vinifera L.) in two soils with contrasting levels of phosphorus. Applied Soil Ecology, 36(2-3): 205-215.

Shamshuddin, J. \& Anda, M. (2012). Enhancing the productivity of ultisols and oxisols in Malaysia using basalt and /or compost. Pedologist, 55(3): 382-391.

Shariah, U. (2013). Terung asam Sarawak, a Geographical Indication (GI) - registered product of Sarawak. Semongok Agriculture Research Centre, Department of Agriculture Sarawak.

Shariah, U., Rajmah, M.R., Wong, M.H. \& Nur, N.H. (2013). Terung asam Sarawak technology package. Sarawak, Malaysia, Department of Agriculture Sarawak.

Sman, C. (2017). 'Terung asam Sarawak can bring lucrative income' - The Borneo Post Online. Downloaded on $19 \quad$ May 2017 https://www.theborneopost.com/2017/05/19/terungasam-sarawak-can-bring-lucrative-income/

Smith, S.E. \& Read, D.J. (2010). Mycorrhizal Symbiosis. Cambridge, MA, USA, Academic Press.

Song, J. (2017). The relationship of root system with the growth and development of bulbs and shoots in lilies. Horticulture Science, 52(2): 245-250.

Subhashini, D.V. (2016). Effect of NPK fertilizers and co-inoculation with phosphate-solubilizing arbuscular mycorrhizal fungus and potassiummobilizing bacteria on growth, yield, nutrient acquisition, and quality of tobacco (Nicotiana tabacum L.). Communications in Soil Science and Plant Analysis, 47(3): 328-337.

Sun, J., Wang, M., Lyu, M., Niklas, K.J., Zhong, Q., Li, M. \& Cheng, D. (2019). Stem diameter (and not length) limits twig leaf biomass. Frontiers in Plant Science, 10:185.

Tan, K.H. (2005). Soil Sampling, Preparation and Analysis. (2nd Edition.) Florida, USA, CRC Press. pp. 154-174.

Teste, F.P., Laliberté, E., Lambers, H., Auer, Y., Kramer, S. \& Kandeler, E. (2016). Mycorrhizal fungal biomass and scavenging declines in phosphorus-impoverished soils during ecosystem retrogression. Soil Biology and Biochemistry, 92: 119-132. 
Thangasamy, A. \& Chavan, K.M. (2017). Assessment of dry matter accumulation and nutriet uptake pattern of garlic. Indian Journal of Horticulture, 74(1): 80-84.

Trejo, D., Ferrera-Cerrato, R., Garcia, R., Varela, L., Lara, L. \& Alarcon, A. (2011). Effectiveness of native arbuscular mycorrhizal fungi consortia on coffee plants under greenhouse and field conditions. Revista Chilena de Historia Natural, 84(1): 23-31.

van der Heijden, Marcel, G.A. \& Sanders, I.R. (2002) (Eds). Mycorrhizal ecology: synthesis and perspectives. In: Mycorrhizal Ecology. Berlin, Heidelberg, Springer. pp. 441-456.
Wang, M., Wu, C., Cheng, Z. \& Meng, H. (2015) Growth and physiological changes in continuously cropped eggplant (Solanum melongena L.) upon relay intercropping with garlic (Allium sativum L.). Frontiers in Plant Science, 6: 262.

Ziane, H., Meddad-Hamza, A., Beddiar, A. \& Gianinazzi, S. (2017). Effects of arbuscular mycorrhizal fungi and fertilization levels on industrial tomato growth and production. International Journal of Agriculture \& Biology, 19: 341-347. 